\title{
Újabb lipidológiai evidenciák és ajánlások
}

\author{
Bajnok László dr. \\ Pécsi Tudományegyetem, Általános Orvostudományi Kar, Klinikai Központ, \\ I. Belgyógyászati Klinika, Endokrinológiai és Anyagcsere Tanszék, Pécs
}

\begin{abstract}
A koleszterinszint és a kockázat mérséklődésének összefüggése unikum: extrém alacsony szinteken sem rajzolódik ki J-görbe. A PRECISE-IVUS szerint akut coronariaszindróma után markánsabb az intenzív koleszterinszint-csökkentésnek a plakkregresszióra gyakorolt hatása, mint krónikus coronariabetegségben. Az IMPROVE-IT során ezetimibbel elért LDL-C-csökkenés ( $1,4 \mathrm{mmol} / \mathrm{l}$, szemben a statinmonoterápia 1,8 mmol/l értékével) jelentősége több nemzetközi irányelvben is kifejezésre került, és a kombinált koleszterinszint-csökkentés javallati köre szélesedett, erőssége fokozódott. Erős bizonyítékaink vannak arra nézve, hogy a statin melletti myalgia általában nem statin okozta következmény, és nem szer- vagy dózisfüggő. Kitartással a betegek többsége statinszedővé tehető, jó életminőség mellett is; aki mégsem, annál az ezetimibmonoterápia alternatíva lehet. Bár általában az intenzív koleszterinszintcsökkentés is biztonságos, hangsúlyt kell fektetni a statinmyopathia elkerülésére. A koleszterinszint-csökkentés kiemelkedő hatékonysága és biztonságossága ellenére az elmúlt években a hazai statinforgalmi adatok visszaestek, amiben alapvető szerepet játszhat a készítményekkel szemben gerjesztett laikus közhangulat. Ez ellen mindenkinek - lehetőségei szerint - tennie kell.
\end{abstract}

Orv Hetil. 2018; 159(32): 1303-1309.

Kulcsszavak: koleszterinszint-csökkentés, lipidológia, cardiovascularis kockázat, kockázat/haszon arány, irányelvek

\section{Newer evidences and recommendations in lipidology}

The correlation between cholesterol and risk reduction is unique: no J curve is seen even at extreme low levels. According to PRECISE-IVUS, the effect of intensive cholesterol lowering on plaque regression is more pronounced post-myocardial infarction syndrome than in chronic coronary disease. The importance of LDL-C lowering with ezetimibe in IMPROVE-IT ( $1.4 \mathrm{mmol} / \mathrm{L}$ compared to $1.8 \mathrm{mmol} / \mathrm{L}$ in the statin monotherapy arm) is expressed in several international guidelines and the indication spectrum of combination cholesterol lowering has broadened and strengthened. There is a strong evidence that myalgia during statin treatment is generally not caused by statins and it is not related to type or dose of the drug. With patience, the majority of patients can be made to become statin takers even with good quality of life; for those who cannot, ezetimibe monotherapy can be an alternative. Even though intensive cholesterol lowering is safe, avoiding statin myopathy should be emphasized. Despite the outstanding efficacy and safety of cholesterol lowering, Hungarian statin sales have decreased recently, in which driven dilettante public climate around the products may be of utmost importance. Everyone of us should counteract this according to the possibilities.

Keywords: cholesterol lowering, lipidology, cardiovascular risk, risk/benefit ratio, guidelines

Bajnok L. [Newer evidences and recommendations in lipidology]. Orv Hetil. 2018; 159(32): 1303-1309.

(Beérkezett: 2018. május 17.; elfogadva: 2018. június 13.)

\section{Rövidítések}

$\mathrm{AACE} / \mathrm{ACE}=($ American Association of Clinical Endocrinologists/American College of Endocrinology) Klinikai Endokrinológusok Amerikai Társasága/Endokrinológia Amerikai Kollégiuma; $\mathrm{ACC} / \mathrm{AHA}=$ (American College of Cardiology $/$ American Heart Association) Amerikai Kardiológiai Társaságok; ACS = (acute coronary syndrome $)$ akut coronariaszindró- ma; $\mathrm{CK}=($ creatinine kinase $)$ kreatinin-kináz; $\mathrm{FH}=$ (familial hypercholesterolemia) familiaris hypercholesterinaemia; GAUSS-3 = Efficacy and Tolerability of Evolocumab vs Ezetimibe in Patients With Muscle-Related Statin Intolerance: The GAUSS-3 Randomized Clinical Trial; GLAGOV = Effect of Evolocumab on Progression of Coronary Disease in StatinTreated Patients: The GLAGOV Randomized Clinical Trial; 
GOT, GPT = aminotranszferáz májenzimek; EAS = (European Atherosclerosis Society) Európai Atherosclerosis Társaság; $\mathrm{ESC}=($ European Society of Cardiology $)$ Európai Kardiológiai Társaság; HOPE-3 = Cholesterol lowering in intermediate-risk persons without cardiovascular disease; $\mathrm{HR}=$ (hazard ratio) kockázati arány; IDEAL = Incremental Decrease in End Points Through Aggressive Lipid Lowering study; INR = (international normalised ratio) nemzetközi normalizált arány; IVUS = (intravascular ultrasound) intracoronariás ultrahang; JUPITER = Justification for the Use of Statins in Primary Prevention: An Intervention Trial Evaluating Rosuvastatin trial; LDL-C = (low-density cholesterol) alacsony sưrűségű koleszterin; PCI = percutan coronariaintervenció; PCSK9 $=($ proprotein convertase subtilisin/kexin type 9) proproteinkonvertáz szubtilizin/ kexin-9; PRECISE-IVUS = Impact of Dual Lipid-Lowering Strategy With Ezetimibe and Atorvastatin on Coronary Plaque Regression in Patients With Percutaneous Coronary Intervention: The Multicenter Randomized Controlled PRECISE-IVUS Trial; PROSPER = Pravastatin in elderly individuals at risk of vascular disease trial; SAMS $=$ (statin-associated muscle symptoms) statinnal kapcsolatos izomtünetek; $\mathrm{Tg}=$ (triglyceride) triglicerid; $\mathrm{TSH}=$ (thyroide-stimulating hormone) thyreoideastimuláló hormon; TNT = Treating to New Targets study; PROVE-IT = PRavastatin Or atorVastatin Evaluation and Infection Therapy (TIMI 22) trial; SPARCL = The Stroke Prevention by Aggressive Reduction in Cholesterol Levels trial

A vér koleszterinszintjének tudatos csökkenését alapvetően a familiaris hypercholesterinaemia $(\mathrm{FH})$ patomechanizmusainak megismerése segítette [1]. Az általában kihasznált mechanizmus azon alapul, hogy a májsejt koleszterintartalmának mérséklésével a májsejtek felszínén fokozható azon receptorok száma, melyek a legfőbb koleszterinhordozó, az alacsony sürűségü lipoprotein partikulum (LDL) megkötését és májsejtbe juttatását végzik [1]. A májsejtek koleszterintartalmának mérséklése történhet a koleszterinbevitel vagy -felszívódás csökkentésével, valamint a májsejt múködésének direkt farmakológiai befolyásolásával, a legtöbbször a koleszterin szintézisének gátlásával. A legújabb áttörést a FH-n belül is ritka forma azonosítása és kiaknázása révén lehetett elérni [1]. Kiderült, hogy a proprotein convertase subtilisin/kexin type 9 (PCSK9) elnevezésü, máj által szintetizált és vérben keringő fehérje csökkenti az LDL-receptorok számát, és a PCSK9 gátlása 60\% körüli LDL-C-csökkenést eredményez. A koleszterinszint és a kockázat mérséklődésének összefüggésében nem rajzolódik ki Jgörbe, hanem extrémen alacsony koleszterinszintig $(0,2$ $\mathrm{mmol} / \mathrm{l}$ LDL-C) követhető a szigorúan monoton függvény, mellékhatásokban mutatkozó különbségek nélkül [2]. A koleszterinszint-csökkentés ráadásul a legbiztonságosabb gyógyszeres kezelési formák közé tartozik [3]; a sok százezer, véletlen besorolásos, placebokontrollált betegév igazolta kiemelkedő hatékonyság és biztonságosság anakronisztikusan éles ellentétben áll a laikus általános közvélekedéssel. Ennek hatása megmutatkozik a hazai statinforgalmi adatok elmúlt években mérhető viszszaesésében is (1.ábra).

\section{A koleszterinszint-csökkentés és a coronariaplakkok méretének változása újabb vizsgálatokban}

A koleszterincsökkentő vizsgálatokból az rajzolódott ki, hogy 2,1 mmol/1 körüli LDL-C-nél megy át a coronariaplakk-progresszió regresszióba [4]. Egy újabb vizsgálat, a PRECISE-IVUS is jól illeszkedett az LDL-C-mérséklődés és az atheromák méretének százalékos csökkenése közötti korrelációs egyeneshez. Ebben a vizsgálatban a (biztonsági szempontok figyelembevételével) maximálisra titrált dózisú atorvastatinhoz képest az atorvastatin + ezetimib mellett az 1,8 mmol/1 alatti LDL-C-célértéket nagyobb arányban lehetett elérni [4]. A statinkezelés mellé adott ezetimib számottevően kifejezettebbé tette a plakkok százalékos regresszióját is. Maga a plakkregresszió ténye is gyakrabban következett be (a betegek $78 \%$-ában, szemben a monoterápia $58 \%$-os arányával, $\mathrm{p}=0,004)$, annak ellenére, hogy az LDL-Ckülönbség az ágak között mérsékelt (mindössze 0,27 $\mathrm{mmol} / 1$ körüli) volt $-1,91 \mathrm{mmol} / 1$ vs. 1,64. A vizsgálatban az igazán meglepő az akut coronariaszindróma (ACS) utáni markáns hatás volt: míg a teljes (stabil coronariabetegeket is magában foglaló) vizsgálati csoport esetében a különbség $-1,4 \%$ vs. $-0,3 \%(\mathrm{p}<0,001)$ volt, ACS után ez $-2,3 \%$ vs. $-0,2 \%$ lett!

Hasonló eredményt adott egy másik intracoronariás ultrahang (IVUS-) alapú vizsgálat, a GLAGOV, amelyben stabil és általában inzufficiens statinkezelés mellé - placebokontrolláltan - PCSK9-gátló evolocumabot kaptak a betegek [5]. A regressziót mutatók aránya $67 \%$ vs. $47 \%$ volt. Ez az eredmény ugyan szerénynek tünik a két ág közötti drámai LDL-C-különbség fényében (2,58 vs. $0,95 \mathrm{mmol} / \mathrm{l})$, azonban a beválogatás és végrehajtás körülményei alapvető tompító szerepet játszhattak. Ez volt ugyanis az első IVUS-vizsgálat, melyben statin-előkezelést követően kerültek a betegek bevonásra (a populáció nem közvetlenül ACS utáni volt). A 18 hónapos követési idő is rövidnek számít. Egy post hoc elemzés viszont arra mutatott rá, hogy ha az induló LDL-C 1,8 mmol/1 alatti volt - amikor az evolocumabbal elért átlagos LDL-C 0,62 mmol/1 lett (!) -, plakkregresszió a betegek $80 \%$-ában következett be (de ez azt is jelezte, hogy a plakkprogresszióért nemcsak az LDL a felelős, hanem egyéb tényezők is).

\section{A lipidszintek javításának lehetőségei és célértékei az ajánlásokban}

$\mathrm{Az}$ atherogen lipidszint európai célértékeit az 1. táblázatban tüntettük fel [1]. A szigorú célérték elérésére és/vagy legalább 50\%-os csökkentésére irányuló erőfeszítéseink során általában intenzív koleszterincsökkentésre van szükség. A populáció közel felében (a medián feletti induló LDL-C-érték és/vagy az átlagosnál renyhébben reagálók esetében) a szigorú célok statinmonoterápia mellett elvileg sem érhetők el, még maximális dózis mellett sem. 


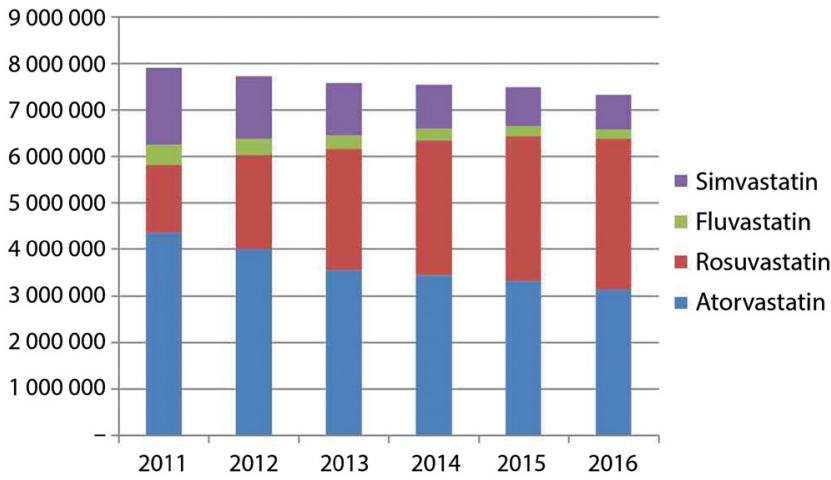

1. ábra

Kiváltott statin dobozforgalmi adatok (OEP/NEAK). Forrás: http://www.neak.gov.hu/felso_menu/szakmai_oldalak/publikus_forgalmi_adatok/gyogyszer_forgalmi_adatok

Ilyenkor egyéb szer, például ezetimib megfontolandó, (IIa ajánlás) vagy PCSK9-gátló (IIb ajánlás) hozzáadása segíthet [1]. Mint lentebb részletezzük, egyes újabb ajánlások bizonyos esetekben primer kombinált koleszterincsökkentést javasolnak, legalább megfontolásra.

$\mathrm{Ha}$ a triglicerid ( $\mathrm{Tg}$ ) emelkedett, a számolt LDL-C helyett a koleszterin és a HDL-C különbségéból képzett másik atherogenlipidszint-paraméter, a non-HDL-C használata célszerü $(4,5$ feletti Tg-nél már egyáltalán nem számolandó az LDL-C). Ha a Tg<4,5 (de még jobb, ha <2,3) mmol/1, az LDL-C Friedewald szerint számítható (és számítandó): a non-HDL-C-ból a Tg 45\%-át levonjuk [1]. A magasabb trigliceridszint és/ vagy alacsonyabb HDL-C cardiovascularis kockázati tényező, azonban gyógyszeres befolyásolásának jelentősége az Európai Atherosclerosis Társaság (EAS) ajánlásában is visszasorolódott (célértékük eddig sem volt): így a statin mellé adott fibrát IIa-ból (megfontolandó) 2016ban IIb lett (megfontolható) [1].

Az LDL-C (és non-HDL-C) európai célértékek a kockázati kategóriák szerint. A 2. oszlop az ajánlás erősségét jelzi, négyfokozatú skálán, amely szerint valamely eljárás I.: ajánlott/javasolt, IIa: megfontolandó. A 3. oszlop a bizonyítékok minőségét jelzi, háromfokozatú skálán: A: több randomizált kontrollált vizsgálatból vagy metaanalízisből származó adatok, B: egy randomizált kontrollált vizsgálatból vagy több nagy, nem randomizált vizsgálatból származó adat, C: szakértők egybehangzó véleménye, illetve kis és/vagy retrospektív vizsgálatból vagy regiszterből származó adatok

\begin{tabular}{lll}
\hline Ajánlás & Osztály & Szint \\
\hline $\begin{array}{l}\text { Igen magas KV kockázatnál LDL-C-cél: } \\
<1,8 \mathrm{mmol} / 1 \text { (non-HDL-C-cél: }<2,6 \mathrm{mmol} / \mathrm{l})\end{array}$ & $\mathrm{I}$. & $\mathrm{B}$ \\
$\begin{array}{l}\text { vagy, ha a kezdeti LDL-C 1,8 és } 3,5 \mathrm{mmol} / 1 \\
\text { közötti, legalább 50\%-os csökkentés }\end{array}$ & & \\
\hline $\begin{array}{l}\text { Magas KV kockázatnál LDL-C-cél: <2,6 mmol/1 } \\
\text { (non-HDL-C-cél: }<3,4 \text { mmol/l) vagy, ha a }\end{array}$ & $\mathrm{B}$ \\
$\begin{array}{l}\text { kezdeti LDL-C } 2,6 \text { és } 5,1 \text { mmol/1 közötti, } \\
\text { legalább 50\%-os csökkentés }\end{array}$ & \\
\hline $\begin{array}{l}\text { Alacsony vagy közepes KV kockázatnál, } \\
\text { koleszterincsökkentő mellett megfontolandó } \\
\text { LDL-C-cél: }<3,0 \text { mmol/1 (non-HDL-C-cél: } \\
<3,8 \text { mmol/1) }\end{array}$ & & \\
\hline
\end{tabular}

$\mathrm{KV}=$ cardiovascularis
Az amerikai ACC/AHA koleszterincsökkentő irányelv - szemben az európaival - nem határoz meg célértéket, de ha az atheroscleroticus cardiovascularis betegség intenzív statinkezelése mellett - atorvastatin esetén $80 \mathrm{mg}$ preferálásával - az LDL-C csökkenésének mértéke nem éri el az 50\%-ot, vagy abszolút értéke 2,6 (társuló diabetes esetén 1,8$) \mathrm{mmol} / \mathrm{l}$ felett marad, további lépések megfontolandók, így kombinált kezelés, első lépésben ezetimib, másodikban PCSK9-gátló [6]. Megjegyzendő, hogy szuboptimális statinválasz esetén a kombinált kezelés - így az ezetimib - primer prevencióban is megfontolandóvá vált, nemcsak hypercholesterinaemiában [6].

Az olasz lipidajánlás ACS kapcsán $80 \mathrm{mg}$ atorvastatint javasol rutinszerüen, primer ezetimibkombinációban diabetes esetén (megfontolásra), illetve 4,2 mmol/1 feletti spontán LDL-C mellett (határozottan); $40 \mathrm{mg}$ atorvastatin csak kivételesen elegendő (ha nem történt PCI, nincs diabetes, nem volt előzetes statinkezelés, és az LDL-C így sem éri el a 2,86 mmol/l-t) [7].

$\mathrm{Az}$ IMPROVE-IT során ezetimibbel elért LDL-Ccsökkenés $(1,4 \mathrm{mmol} / 1$, szemben a statinmonoterápia 1,8 mmol/1 értékével) pozitív cardiovascularis hatása a fentieken túl is beépült a nemzetközi ajánlásokba [8]. A Klinikai Endokrinológusok Amerikai Társasága és az Endokrinológia Amerikai Kollégiuma (American Association of Clinical Endocrinologists and American College of Endocrinology; AACE/ACE) 2017. évi dyslipidaemiaajánlásában meghatározásra került egy extrémen magas kockázati kategória is - ehhez tartozó, 1,4 mmol/1 alatti LDL-C-célértékkel [9]. Idesorolódnak azok, akiknél az atheroscleroticus cardiovascularis betegség (i) progreszszív, így 1,8 mmol/1 alatti LDL-C ellenére ACS következik be, (ii) olyan betegségekkel társult, mint a diabetes, 3. vagy 4. stádiumú idült vesebetegség, illetve familiaris hypercholesterinaemia, vagy (iii) korai kezdetű (férfi esetében 55, nőnél 65 év előtti). A francia, ACS utáni lipidellátásra vonatkozó útmutató pedig ezetimib hozzáadását javasolja, ha az alkalmazott statinmonoterápiával az LDL-C a célérték felett marad. Az utóbbi 1,8 mmol/1 vagy 1,4 mmol/1, attól függően, hogy - sorrendben mérsékelt vagy intenzív-e az alkalmazott statindózis [10]. (Mint láttuk, az 1,4 mmol/1 alatti LDL-C általában nem érhető el statinmonoterápiával.)

A Magyar Kardiovaszkuláris Konszenzus Konferencia koleszterincsökkentő irányelvei alapvetően az EAS-ajánlással harmonizálnak.

\section{A statinok mellékhatásai és szövődményei}

A kérdést a negatív közhangulat okán is indokolt áttekintenünk.

\section{Statinnal kapcsolatos izomtïnetek}

A statinnal kapcsolatos izomtüneteket együttesen szokás tárgyalni, SAMS-ként rövidítve (statin-associated muscle symptoms) [11, 12]. Két fó formáját képezik a szubjektív izompanaszok és a statinmyopathia. 


\section{A szubjektív izompanaszok és kezelésük}

A statinszedéssel kapcsolatba hozott izompanaszok (fájdalom, görcs, gyengeség) mechanizmusa nem kellően tisztázott, komplex lehet, kreatinin-kináz (CK)-emelkedés általában nem kíséri $[12,13]$. (Az ízületi panaszok nem tekinthetők statinmellékhatásnak.) Gyakorisága a megfigyeléses vizsgálatokban 5-20\% közöttire tehetó, azonban a véletlen besorolásos, ellenőrzött vizsgálatok metaanalízisében ez legalább egy nagyságrenddel ritkább, ami nem magyarázható pusztán a vizsgálatok betegszelekcióival [3]. A HOPE-3-ban például 4,7\% volt az izomtünetek gyakorisága a placebo- és mindössze $5,8 \%$ a rosuvastatinágon (HR: $1,23, p=0,005)$ [14]. Vagy, az előzetesen „abszolút” statinintoleránsnak minősíthetőkön végzett GAUSS-3 bevezetô szakaszában a betegek véletlenszerúen $20 \mathrm{mg}$ atorvastatint vagy placebót kaptak [15]. A kezelést elhagyók aránya 42,6\% volt az atorvastatin és $26,5 \%$ a placebo mellett. Tehát a statin melletti myalgia még ilyen, válogatott esetekben is gyakrabban nem ismétlődik, mint igen, és ha mégis, gyakrabban a statinhatás (lehetőségének a) tudata, mint maga a statin okozza. A betegtájékoztató ugyanis fokozza ezt az úgynevezett nocebohatást [16]. Ezért vezető szakértók egészében megkérdőjelezik a statinintoleranciát, idézőjelbe téve azt [3]. A dózis vagy szer szerinti különbség - szemben a myopathiával és a rhabdomyolysissel - még kevésbé alapul bizonyítékokon. Így a 80 mg-os dózist összehasonlító kettôs vak klinikai vizsgálatok közül nemcsak az atorvastatinosok esetében (PROVE-IT, TNT, SPARCL) nem volt különbség a myalgia gyakoriságában, hanem - az A-Z és SEARCH vizsgálatokban, az egyébként a lent részletezett myopathia tekintetében ma már nem biztonságosnak tekintett - $80 \mathrm{mg}$ adagú simvastatin mellett sem volt meggyőző differencia. Az esetek nagyobb részében a myalgia a kezelés első hónapjaiban jelentkezik, alkalmi és újraalkalmazáskor nem ismétlődik [12]. A statinmyalgia elleni stratégiát az ESC kitüntetett hangsúllyal kezeli $[1,12]$. Ennek lényegét a 2. táblázatban tüntettük fel. A táplálékkiegészítők, vitaminok nem jelentenek alternatívát, sem a koleszterinszint-csökkentésben, sem a SAMS ellen [12], hanem az állhatatosság a leghatékonyabb eszközünk. Abszolút intoleráns esetben ezetimib- vagy fibrátmonoterápia, esetleg a kettő kombinációja jön szóba.

\section{A statinmyopathia és megelözése}

A valóban statin okozta, a normális felső határának tízszeresét meghaladó CK-emelkedéssel járó myopathia gyakorisága a véletlen besorolásos vizsgálatokban 1 : 10000 betegév körüli, a myoglobinaemiával és veseelégtelenség kockázatával járó rhabdomyolysisé l : 50000 betegév [3]. A statinkészítmények - a szükséges, lentebb tárgyalt óvatossági szabályok mellett, még intenzív dózisban is - általában biztonságosak [13]. A myopathia és a rhabdomyolysis kockázatát fokozó tényezőket a 3. táblázatban összegeztük. Ezek közül kiemelkedik az a konstelláció, amikor két vagy három tényező együtt van a következőkből: (i) 70 év feletti kor, (ii) a női nem, (iii) alacsony testsúly. A (sokszor fel nem ismert, koleszterinszintet is emelö) hypothyreosis is jelentősen fokozza a statinmyopathia kockázatát. Ezért különösen idősebb nőkön indokolt a hypothyreosis TSH-val történő szúrése [17]. Ha az eGFR $<60 \mathrm{ml} / \mathrm{min} / 1,73 \mathrm{~m}^{2}$, rosuvastatinból maximum $20 \mathrm{mg}$ adható, $30 \mathrm{ml} / \mathrm{min} / 1,73$ $\mathrm{m}^{2}$ alatt pedig a kevesebb is ellenjavallt. Ezzel szemben az atorvastatin nem kumulálódik jelentősen veseelégtelenségben, de meg kell jegyezni, hogy ilyenkor atorvastatinnal is nagyobb a myopathia kockázata, mert maga a krónikus vesebetegség csökkenti a statinnal szembeni ellenálló képességet $[12,13]$. Hasonló a helyzet diabetes mellitus és hypertriglyceridaemia esetén (ilyenkor az izmok jellegzetesen csökkent mitokondriális múködése fokozza a myopathia kockázatát). Ha ezen tényezők közül az abszolút korlátokat képezőket kivesszük (első-

2. táblázat |A statinmyalgia elleni stratégiák

\begin{tabular}{ll}
\hline 1. & $\begin{array}{l}2-4 \text { hét statinszünet után ismét ugyanaz a statin csökkentett } \\
\text { vagy azonos adagban }\end{array}$ \\
\hline 2. & $\begin{array}{l}2-4 \text { hét statinszünet után másik hosszú hatású statin, kis } \\
\text { dózissal indítva, majd feltitrálva }\end{array}$ \\
\hline 3. & $\begin{array}{l}2-4 \text { hét statinszünet után kis dózisú rosuvastatin vagy } \\
\text { atorvastatin } 2 \text { vagy } 3, \text { esetleg } 7 \text { naponta, majd dózistitrálás }\end{array}$ \\
\hline 4. & $\begin{array}{l}2-4 \text { hét statinszünet után, kisebb adagban fluvastatin vagy } \\
\text { pravastatin, majd dózistitrálás }\end{array}$ \\
\hline 5. & Ezetimibmonoterápia \\
\hline 6. & Fibrátmonoterápia \\
\hline
\end{tabular}

3. táblázat |A myopathia és a rhabdomyolysis kockázatát fokozó tényezók

\begin{tabular}{l}
\hline 70 év feletti kor \\
\hline Női nem \\
\hline Alacsony testsúly \\
\hline Hypothyreosis \\
\hline Alkoholizmus \\
\hline Diabetes mellitus \\
\hline Hypertriglyceridaemia \\
\hline Veseelégtelenség \\
\hline Gyógyszer-interakciók \\
\hline Májbetegség \\
\hline Reumatológiai betegségek \\
\hline Szteroidszedés \\
\hline Hypalbuminaemia \\
\hline Akut interkurrens betegség \\
\hline Perioperatív időszak \\
\hline Nagy fizikai megterhelés \\
\hline Öröklődó izombetegségek (vagy családi elözményben) \\
\hline CK-emelkedés az előzményben \\
\hline
\end{tabular}


sorban a hypothyreosist és veseelégtelenségben a rosuvastatint), önmagában egyik sem szokta abszolút ellenjavallatát képezni a maximális dózis alkalmazásának.

A simvastatin és az atorvastatin gyakoribb farmakokinetikai gyógyszer-interakcióit a 4. táblázatban összegeztük. A napi gyakorlatban a klaritromicin és az itrakonazol jelenti a legnagyobb veszélyforrást (szemben a sokkal kisebb kumulálódást előidéző azitromicinnel és flukonazollal) [18]. Ritkább, de igen jelentős az antifungális vorikonazol, az antiretrovirális vagy transzplantáció utáni kezelés interakciója (ciklosporinnal például csak fluvastatin adható, maximum $40 \mathrm{mg}$-os adagban) [18]. Az antidepresszánsok közül a fluoxetin, szertralin, az antipszichotikumok közül a riszperidon, kvetiapin esetében számolhatunk mérsékelt fokú simvastatin- vagy atorvastatin-vérszintemelkedést okozó citokróm P450 3A4 interakcióval, de az alprazolám, bizonyos altatók, a tamoxifen és a szildenafil is hasonló hatású lehet [18]. Myopathiához vezető farmakodinámiás statininterakció előfordulhat neurolepticumokkal, nemszteroid gyulladásgátlókkal, az anesztézia szereivel, alkohollal vagy egyéb tudatmódosító szerekkel.

Bizonyos esetekben - elsősorban 70 éves kor felett, krónikus vese- vagy májbetegség, alkoholizmus társulásakor - a CK meghatározása a kezelés előtt indokolt [12, 13]. A referenciatartomány felső határának négyszeresét meghaladó CK-emelkedés ellenjavallatot képez (és egyben az eredet meghatározásának szükségességét is - fizikai megeróltetés, trauma, izomgörcsök, intramuscularis injekció stb.). Induláskor mért, kontraindikációt nem képező CK-emelkedés vagy izompanaszok esetén szükséges a kezelés megkezdését követő CK-vizsgálat, egyébként rutinszerúen nem $[12,13]$.

A fenofibrát nem mutat érdemi farmakokinetikai interakciót a statinokkal, de farmakodinámiás negatív együtthatásuk lehet (fibráttal együtt rosuvastatinból sem adható $20 \mathrm{mg}$-nál több) [18]. A veseelégtelenség szintén befolyásolja a fenofibrát alkalmazhatóságát.

\section{A statinok diabetogén hatása}

A statinok az új keletű diabetes mellitus kialakulásának relatív kockázatát, mérsékelten, dózisfüggő módon, 9-26\%-kal emelik [3, 11, 19, 20]. A kardiometabolikus nettó haszon : kockázat arány markánsan pozitív, körül-

4. táblázat $\mid$ A simvastatin és az atorvastatin gyakoribb farmakokinetikai gyógyszer-interakciói

\begin{tabular}{lc}
\hline $\begin{array}{l}\text { Verapamil, diltiazem, K-vitamin-antagonista, digoxin, } \\
\text { amiodaron }\end{array}$ & + \\
\hline Flukonazol, roxitromicin, azitromicin & + \\
\hline Itrakonazol, klaritromicin & ++ \\
\hline
\end{tabular}

Koncentrációemelkedés $<100 \%$

Koncentrációemelkedés $>200 \%$ belül kilenc az egyhez. A diabetogén hatás patomechanizmusa elsősorban az inzulinelválasztás zavarával kapcsolatos (egyes adatok az inzulinrezisztencia fokozódása mellett is szólnak). A kockázat függ az olyan egyéb kockázati tényezőktől is, mint az életkor vagy a metabolikus szindróma esetleges fennállása. Az alkalmazott statin fajtájának jelentősége vitatott $[3,9,11]$ (három individuális vizsgálatban volt szignifikáns gyakoriságnövekedés: a pravastatinnal végzett PROSPER-ben, a TNT-ben, 80 mg atorvastatin mellett és az intenzív rosuvastatinos JUPITER-ben [19, 20]). A hypercholesterinaemia kettes típusú diabetesszel szembeni védőhatását genetikai vizsgálatok is jelzik $[3,11]$. Ezért is volt különösen érdekes megismerni, hogy mi a hatása a koleszterinszintcsökkentés nem statinnal történő intenzifikálásának az új diabetes incidenciájára. Sem az ezetimib, sem a PCSK9gátló evolocumab mellett nem lett több diabetes [11, $21,22]$.

\section{A statinnal kapcsolatos egyéb lehetséges mellékhatások}

A potenciális - de véletlen besorolásos nagy vizsgálatok által nem igazolt - mellékhatások közé tartozik a hasi fájdalom, a székrekedés, a hányinger, a fejfájás, a gyengeség, a szédülés, a szexuális zavarok és a depresszió [17]. Ezek pontos prevalenciáját nehéz megállapítani, de biztosan sokkal ritkábbak, mint azt a betegtájékoztatók sugallják. Az 500000 betegévet meghaladó véletlen besorolásos adatbázis nem jelez esetleges karcinogén hatást sem [3]. Több, legmagasabb szintű szakértői grémium állapította meg, hogy a statinok nem fokozzák a kognitív diszfunkció, a neuropathia, a cataractaképződés és a myocytotoxicitas kockázatát sem $[3,11]$. Vitatott, hogy gyakoribb-e a vérzéses stroke $[3,11]$.

A statinszedés egyik akadálya a májkárosodástól való, a közhiedelemben elterjedt félelem. Ezzel szemben a súlyos, statin okozta hepatopathia nagyon ritka (<1/10 000), és a progresszív idült és/vagy fatális esetek megszaporodását megbízható adatbázisokban nem lehetett kimutatni. Ezért legújabban a májenzimek statinkezelés elkezdése utáni rutinellenőrzését nem javasolják (a kezelés előtti vizsgálatok szükségesek maradtak) [1, 3] - a National Lipid Association azért nem, mert az emelkedett értékek eltántoríthatják a klinikusokat a folytatástól [23]. Ellenjavallatot csak a háromszoros GPT- vagy GOT-emelkedés képez. A véletlen besorolásos vizsgálatokban is kimutatható - szemben a SAMS-sal -, hogy az atorvastatin $80 \mathrm{mg}$-os adagja mellett a májenzim-emelkedés szignifikánsan gyakoribb, mint mérsékelt intenzitású statinrezsim esetében [24]. Összességében a statin okozta májenzim-emelkedés gyakorisága, dózistól és szertől függően, $0,2-2,1 \%$ közötti, rosuvastatin mellett ritkább, mint atorvastatin mellett [25]. Bizonyos vizsgálatok arra utaltak, hogy a - döntően zsírmájjal kapcsolatos májenzim-emelkedést - a statinszedés nem rontja, hanem javítja [26]. 


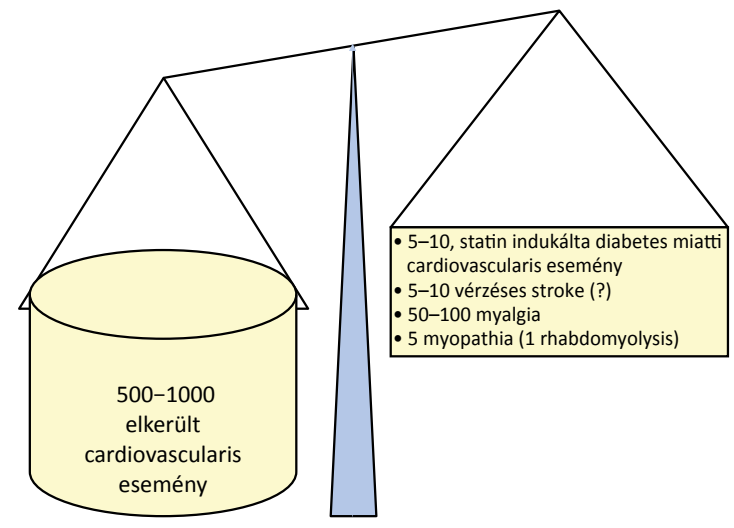

2. ábra

Az intenzív statinkezelés potenciális cardiovascularis haszna és kockázata 10000 beteg 5 éves statinkezelésekor. A kérdőjel azt jelzi, hogy a vérzéses stroke gyakoribbá válása nem teljesen egyértelmú

\section{A statin haszon : kockázat aránya}

A statin haszon : kockázat arányának illusztrálására szolgál a 2. ábra, melyen a bizonyítékokon alapuló események és gyakoriságok szerepelnek (a statinok nem atherosclerosisra gyakorolt pozitív hatásai közül csak a vénás trombózis és embólia kockázatának csökkentése tekinthető kellóen bizonyítottnak) [3]. Az elkerült cardiovascularis események száma alapvetően az abszolút kockázattól függ. Végezzünk egy számítást ennek szellemében, a stabil coronariabetegek bevonásával lebonyolított TNT felhasználásával (5. táblázat)! A vizsgálatban a $80 \mathrm{mg}$ atorvastatin $22 \%$ relatív kockázatcsökkenést eredményezett a $10 \mathrm{mg}$-hoz képest, miközben a SAMS nem volt gyakoribb, sem a myalgia (mint ahogy - már korábban említettük - egyik kettós vak 80 mg-os statinvizsgálatban sem), sem a myopathia (mint ahogy másik három nagy, releváns - PROVE-IT, IDEAL, SPARCL - 80 mg-os atorvastatinvizsgálatban sem) [24]. A dózis duplázása ebben a tartományban arányos hatást fejt ki - a koleszterinszint és -kockázat csökkentése és az új diabetes kockázatának fokozása formájában. Tehát extrapolációval a kockázatkülönbségek lépcsőkre oszthatók (magának a

5. táblázat $\mid A z$ atorvastatin dózisduplázásának extrapolált pozitív és negatív hatása a kockázatra, 10000 stabil coronariabeteg 5 éves kezelése során

\begin{tabular}{lcccc}
\hline $\begin{array}{l}\text { Atorvastatin } \\
10 \mathrm{mg}\end{array}$ & MACE-RR & MACE-AR & $\begin{array}{c}\text { + MACE } \\
\text { (+ T2DM } \\
\text { okozta })\end{array}$ & $\begin{array}{c}\text { Izom- } \\
\text { panaszok, } \\
\text { tünetek }\end{array}$ \\
\cline { 3 - 5 } vs. & $-7,33 \%$ & -73 & +2 & $+?$ \\
\hline $20 \mathrm{mg}$ & $-14,66 \%$ & -147 & +4 & $+?$ \\
\hline $40 \mathrm{mg}$ & $-22 \%$ & -220 & +6 & $+?$ \\
\hline $80 \mathrm{mg}$ & & & & \\
\hline
\end{tabular}

\section{*-73}

\section{${ }^{*}+2$}

A kérdőjel a bizonyítékok hiányát jelzi.

$\mathrm{AR}$ = abszolút rizikó; $\mathrm{MACE}=$ major cardiovascularis események;

$\mathrm{RR}=$ relatív rizikó; $\mathrm{T} 2 \mathrm{DM}=2$-es típusú diabetes mellitus
TNT-nek a statisztikai ereje nem lett volna elég ilyen kis cardiovascularis kockázatkülönbségek tényleges demonstrálásához). Mint látható, általánosságban az intenzív statinkezelés tartományán belül - 40 vs. $80 \mathrm{mg}$ - is nagyságrendnyivel nagyobb a várható elóny, mint a bizonyítékokon alapuló mellékhatás.

\section{A koleszterinszint-csökkentés adherenciájának javitása}

Tudatos programot kell folytatnunk a gyógyszerszedési együttmúkoödés javításáért. Például az LDL-C - az INRhez hasonlatosan - beépített marker; ha intenzív statin mellett értéke 2,5 mmol/l (a non-HDL-C-é 3,3 mmol/l) feletti, sokkal valószínúbb (minél magasabb, annál inkább), hogy a beteg nem szedi (pontosan) a gyógyszereit, mint az, hogy a kezelés nélküli koleszterin ilyen magas, és/vagy a statinra adott válasz ilyen gyenge. A páciensek sajnos nem értesülnek a betegtájékoztatóból, hogy a felsorolt mellékhatások nagy része nem bizonyítékokon alapul. (Ha a hatékonyságot csak kettós vakvéletlen besorolásos, ellenőrzött, sok százezer betegév alapú vizsgálatokkal fogadjuk el bizonyítottnak, miért alkalmazunk kettős mércét a mellékhatások esetében?)

Legyen külön stratégiánk az egyre terjedő statinellenes véleményekkel szemben is. Az orvostársadalomra, különösen vezetôire kitüntetett szerep hárul(na) a nyilvánosság modern kezeléseket elutasító megnyilvánulásaival való küzdelemben. A tévhitekkel szembeni tudományos érvelés vesztésre ítélt magyarázkodásnak túnik, egy véleménynek a sok közül. A sarlatánok nézetei viszont óhatatlanul nagyobb teret kapnak, hiszen a vélemény szabad, és a jelenség lényegi eleme az egyszerúbben gondolkodók tudománnyal szembeni lázadása. A közvéleményt a szakembereknek aktívabban kellene tematizálni, például azzal, hogy ha a nemzetközi irányelveket - mindegy, hogy melyiket - következetesen követnénk, arról lehetne releváns vitát folytatni, hogy Magyarországon hány millióval több embernek kellene statint szednie (vagy hány millióval kevesebbnek nem kellene).

\section{Következtetések}

A koleszterinszint-csökkentés területén további intenzitásnövelésre vonatkozó bizonyítékok és nemzetközi ajánlások jelentek meg. Ennek során a kombinációs koleszterinszint-csökkentés szerepe fel-, míg a nem (tisztán) koleszterincélzatú lipidkezeléseké leértékelődött. A koleszterinszint-csökkentők a legjobban bevizsgált készítmények közé tartoznak mind a hatás, mind a mellékhatás tekintetében, így bizton állíthatjuk, hogy mindkét szempontból első osztályúak. Javallt és nem ellenjavallt alkalmazásukkor (legalább egy) nagyságrendnyivel nagyobb a tőlük várható haszon, mint a kockázat, még maximális dózisok esetén is. Mégsem használjuk ki kellóképpen a bennük rejlő lehetőségeket - különösen a legújabb bizonyítékok és ajánlások tükrében van bőven restanciánk. 
Mégis, a legnagyobb problémát a tudománnyal ellentétes irányban mozgó laikus közhangulat jelenti. Mindent meg kell tennünk a gyógyszerszedési együttmúködés javításáért is, kinek-kinek a saját területén.

Anyagi támogatás: A közlemény megjelenését az MSD Pharma Hungary Kft. tette lehetővé.

A szerző a cikk végleges változatát elolvasta és jóváhagyta.

Érdekeltségek: A szerzőnek nincsenek érdekeltségei.

\section{Irodalom}

[1] Catapano AL, Graham I, De Backer G, et al. 2016 ESC/EAS Guidelines for the management of dyslipidaemias. Eur Heart J. 2016; 37: 2999-3058.

[2] Giugliano RP, Pedersen TR, Park JG, et al. Clinical efficacy and safety of achieving very low LDL-cholesterol concentrations with the PCSK9 inhibitor evolocumab: a prespecified secondary analysis of the FOURIER trial. Lancet 2017; 390: 1962-1971.

[3] Collins R, Reith C, Emberson J, et al. Interpretation of the evidence for the efficacy and safety of statin therapy. Lancet 2016; 388: 2532-2561.

[4] Tsujita K, Sugiyama S, Sumida H, et al. Impact of dual lipidlowering strategy with ezetimibe and atorvastatin on coronary plaque regression in patients with percutaneous coronary intervention: the multicenter randomized controlled PRECISEIVUS trial. J Am Coll Cardiol. 2015; 66: 495-507.

[5] Nicholls SJ, Puri R, Anderson T, et al. Effect of evolocumab on progression of coronary disease in statin-treated patients: The GLAGOV randomized clinical trial. JAMA 2016; 316: $2373-$ 2384.

[6] Lloyd-Jones DM, Morris PB, Ballantyne CM, et al. 2017 Focused update of the 2016 ACC expert consensus decision pathway on the role of non-statin therapies for LDL-cholesterol lowering in the management of atherosclerotic cardiovascular disease risk: A Report of the American College of Cardiology Task Force on Expert Consensus Decision Pathways. J Am Coll Cardiol. 2017; 70: 1785-1822.

[7] Colivicchi F, Massimo Gulizia M, Arca M, el al. ANMCO Scientific Statement: clinical management of hypercholesterolaemia in patients with acute coronary syndromes. Eur Heart J Suppl. 2017; 19(Suppl D): D64-D69.

[8] Cannon CP, Blazing MA, Giugliano RP, et al. Ezetimibe added to statin therapy after acute coronary syndromes. N Engl J Med. $2015 ; 372: 2387-2397$

[9] Jellinger PS, Handelsman Y, Rosenblit PD, et al. American Association of Clinical Endocrinologists and American College of Endocrinology Guidelines for Management of Dyslipidemia and Prevention of Cardiovascular Disease. Endocr Pract. 2017; 23: 479-497.

[10] Schiele F, Farnier M, Krempf M, et al. A consensus statement on lipid management after acute coronary syndrome. Eur Heart J Acute Cardiovasc Care 2016 Nov 17. pii: 2048872616679791. [Epub ahead of print]
[11] Mach F, Ray KK, Wiklund O, et al. Adverse effects of statin ther apy: perception vs. the evidence - focus on glucose homeostasis, cognitive, renal and hepatic function, haemorrhagic stroke and cataract. Eur Heart J. 2018 Apr 27. doi: 10.1093/eurheartj/ ehyl82. [Epub ahead of print]

[12] Stroes ES, Thompson PD, Corsini A, et al. Statin-associated muscle symptoms: impact on statin therapy - European Atherosclerosis Society Consensus Panel Statement on Assessment, Aetiology and Management. Eur Heart J. 2015; 36: 1012-1022.

[13] Rosenson RS, Baker SK, Jacobson TA, et al. An assessment by the statin muscle safety task force: 2014 update. J Clin Lipidol. 2014; 8(Suppl): S58-S71.

[14] Yusuf S, Bosch J, Dagenais G, et al., for the HOPE-3 Investigators. Cholesterol lowering in intermediate-risk persons without cardiovascular disease. N Engl J Med. 2016; 374: 2021-2031.

[15] Nissen SE, Stroes E, Dent-Acosta RE, et al. Efficacy and tolerability of evolocumab vs ezetimibe in patients with muscle-related statin intolerance: The GAUSS-3 randomized clinical trial. JAMA 2016; 315: 1580-1590.

[16] Finegold JA, Manisty CH, Goldacre B, et al. What proportion of symptomatic side effects in patients taking statins are genuinely caused by the drug? Systematic review of randomized placebocontrolled trials to aid individual patient choice. Eur J Prev Cardiol. 2014; 21: 464-474.

[17] Banach M, Rizzo M, Toth PP, et al. Statin intolerance - an attempt at a unified definition. Position paper from an International Lipid Expert Panel. Expert Opin Drug Saf. 2015; 14: 935-955.

[18] Kellick KA, Bottorff M, Toth PP. A clinician's guide to statin drug-drug interactions. J Clin Lipidol. 2014; 8(Suppl): S30-S46.

[19] Sattar N, Preiss D, Murray HM, et al. Statins and risk of incident diabetes: a collaborative meta-analysis of randomised statin trials. Lancet 2010; 375: 735-742.

[20] Preiss D, Seshasai SR, Welsh P, et al. Risk of incident diabetes with intensive-dose compared with moderate-dose statin therapy: a meta-analysis. JAMA 2011; 305: 2556-2564.

[21] Blazing MA. Incidence of newonset diabetes in the IMPROVEIT trial: does adding ezetimibe to simvastatin increase risk compared to simvastatin alone? Presented at: European Society of Cardiology Congress, London, September 1, 2015.

[22] Sabatine MS, Giugliano RP, Keech AC, et al. Evolocumab and clinical outcomes in patients with cardiovascular disease. N Engl J Med. 2017; 376: 1713-1722.

[23] Cohen DE, Anania FA, Chalasani N. An assessment of statin safety by hepatologists. Am J Cardiol. 2006; 97: 77C-81C.

[24] LaRosa JC, Grundy SM, Waters DD, et al. Intensive lipid lowering with atorvastatin in patients with stable coronary disease. $\mathrm{N}$ Engl J Med. 2005; 352: 1425-1435.

[25] Nicholls SJ, Ballantyne CM, Barter PJ, et al. Effect of two intensive statin regimens on progression of coronary disease. $\mathrm{N}$ Engl J Med. 2011; 365: 2078-2087.

[26] Athyros VG, Tziomalos K, Gossios TD, et al. Safety and efficacy of long-term statin treatment for cardiovascular events in patients with coronary heart disease and abnormal liver tests in the Greek Atorvastatin and Coronary Heart Disease Evaluation (GREACE) Study: a post-hoc analysis. Lancet 2010; 376: 19161922 .

(Bajnok László dr., Pécs, Ifjúság út 13., 7624 e-mail: bajnok.laszlo@pte.hu)

A közlemény megjelenését az MSD Pharma Hungary Kft. tette lehetővé.

Az itt közölt információk a szerzó véleményét tükrözik, amely eltérhet az MSD Pharma Hungary Kft. álláspontjától. A megemlített termékek használatakor az érvényes alkalmazási előírás az irányadó.

A cikk a Creative Commons Attribution-NonCommercial 4.0 International License (https://creativecommons.org/licenses/by-nc/4.0) feltételei szerint publikált Open Access közlemény, melynek szellemében a cikk nem kereskedelmi célból bármilyen médiumban szabadon felhasználható, megosztható és újraközölhető, feltéve, hogy az eredeti szerző és a közlés helye, illetve a CC License linkje és az esetlegesen végrehajtott módosítások feltüntetésre kerülnek. 